\title{
Evaluation of Inter and Intraspecific Differences in the Venom Chemical Compositions of Polybia paulista Wasps and Ectatomma brunneum Ants Using FTIR-PAS
}

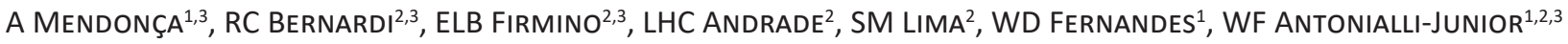 \\ 1- Programa de Pós-graduação em Entomologia e Conservação da Biodiversidade, Universidade Federal da Grande Dourados, Dourados-MS, Brazil \\ 2 - Centro de Estudo em Recursos Naturais, Programa de Pós-graduação em Recursos Naturais, Universidade Estadual de Mato Grosso do Sul, \\ Dourados-MS, Brazil \\ 3-Laboratório de Ecologia Comportamental - LABECO, Universidade Estadual de Mato Grosso do Sul, Dourados-MS, Brazil
}

\section{Article History}

\section{Edited by}

Fernando Noll, UNESP, Brazil

Received

09 December 2018

Initial acceptance 28 January 2019

Final acceptance 24 June 2019

Publication date 14 November 2019

\section{Keywords}

Eusocial insects; exogenous component; genetic component; Vespidae, Formicidae.

\author{
Corresponding author \\ Angelica Mendonça \\ Programa de Pós-graduação em \\ Entomologia e Conservação da \\ Biodiversidade \\ Universidade Federal da Grande Dourados \\ Rodovia Dourados-Itahum, Km 12 \\ Cidade Universitária, C.P. 533 \\ CEP 79804-970, Dourados-MS, Brasil. \\ E-Mail: angel_bio1@yahoo.com.br
}

\begin{abstract}
Wasp and ant venoms represent complex mixtures of compounds such as proteins, peptides, lipids, vasoactive amines, enzymes, besides of amino acids and compounds with low molecular weight. These venoms have as function capture prey and assist in defense of their colonies. Parameters such as geographic location, genetics, environment, sex, age, season of the year, and diet determine the composition of the venom. However, studies on the compositional variability of venom are still limited due to the difficulty in obtaining samples and the complexity of these substances. This work describes the use of the Fourier Transform Infrared Photoacoustic Spectroscopy (FTIR-PAS) to investigate interand intraspecific variability in the venom chemical composition of the social wasp Polybia paulista (Von Ihering 1896) and the ant Ectatomma brunneum (Smith 1858). The results reveal significant differences in venom chemical composition between the ant and wasp, even for samples obtained from the same environment. The genetic component, therefore, seemed to be the predominant factor determining the compounds present. The findings also showed that exogenous factors, such as diet, could also be responsible for intraspecific differences, especially in wasps. The FTIR-PAS technique proved to be a reliable way of assessing intra- and interspecific differences in social Hymenoptera venom chemical composition.
\end{abstract}

\section{Introduction}

The Hymenoptera, one of the most significant orders of insects, is composed of wasps, bees, ants, and sawflies. Within this order, some individuals are eusocial, which have as essential characteristics the division of reproductive labor, cooperative parental care, and overlapping generations (Wilson, 1971).

An essential characteristic of Hymenoptera, specifically the Aculeata, is the presence of a sting apparatus that is used to inject venom into prey and enemies. This sting apparatus, which contains a venom reservoir, is a modification of the ovipositor device from ancestral groups. It consists of two different regions: a glandular portion, where the venom and other substances are produced, and a motor portion composed of chitinous and muscle structures that act together in the injection of venom and sting protrusion and extrusion (Manzoli-Palma \& Gobbi, 1997). Its primary function is to capture prey, but it has become effective in the intimidation of vertebrates. Also, it has acquired a significant defensive role, notably in social species (Macalintal \& Starr, 1996).

Venom is defined as a secretion produced by specialized glands, which is capable of altering or disrupting the normal biological or physiological processes of the target organism (Casewell et al., 2013). In addition to the offensive and defensive functions, volatile compounds present in glandular 
venom can act as an alarm pheromone (Schmidt, 1982; Orivel et al., 2001). Mateus (2011) observed that the Parachartergus fraternus social wasp uses its venom to mark a new site for colony foundation. Thus, venom (or its components) also plays an essential role as chemical communication signal in wasp societies.

Hymenopteran venom consists of complex organic molecules of proteins, peptides, lipids, vasoactive amines (octopamine, dopamine, and histamine), and enzymes such as phospholipases, hyaluronidases, and phosphatases (Edstrom, 1992; Lima \& Brochetto-Braga, 2003). Besides, it is composed predominantly of amino acids and complex mixture of compounds with low molecular weight (Palma, 2006). The venom can have antiseptic activities against bacteria, fungi, protozoa, and viruses (Orivel et al., 2001; Baracchi \& Tragust, 2017). The antiseptic function of venom is part of the innate immunity of Hymenoptera and its initial evolutionary value is associated with the need to minimize potential contamination by prey (Orivel et al., 2001; Baracchi \& Tragust, 2017).

It has been found that variation in venom chemical composition among organisms is related to their geographic position, genetic, environmental conditions, sex, age, diet and also depends on seasonal factors (Daltry et al., 1996; Badhe, 2006; Abdel-Rahman et al., 2009, 2011).

Polybia paulista (Von Ihering, 1896) social wasp is widely distributed in South America (Richards, 1978). This genus builds phragmocyttarus nests without any pedicel, so the first comb is established directly in the substrate, with a protective jacket built around it (Carpenter \& Marques, 2001). The Ectatomma brunneum ant (Smith, 1858) is widely distributed in the Neotropical region, occurring from Panama to Argentina (Kempf, 1992). It is a generalist predator species, with well- developed stingers. The nests are constructed on the ground, with more significant abundance in open fields or degraded areas including pastures, crops, grassland, unpaved roads, and clearings (Gomes et al., 2009).

Although there is a significant number of studies with the venom of P. paulista (Souza et al., 2009; Santo et al., 2011; Pinto et al., 2012; Hoshina et al., 2013; Jacomini et al., 2013; Gomes et al., 2014; Dias et al., 2014, 2015; Leite et al., 2015; Vinhote et al., 2017; Perez-Riverol et al., 2018) and some with the venom of E. brunneum (Pluzhnikov et al., 2014; Touchard et al., 2015; Aili et al., 2016) only a few of them investigated intraspecific differences in venom compositions, for example, P. paulista (Mendonça et al., 2017) and E.brunneum Bernardi et al. (2017). As the occurrence of these two species is ample, they end up being good study models to evaluate intraspecific differences of their venoms.

In the last few years, Fourier Transform Infrared Photoacoustic Spectroscopy (FTIR-PAS) has proven to be a reliable technique for using in comparative studies of the venoms of social Hymenoptera (Bernardi et al., 2017; Mendonça et al., 2017), as well as their cuticular hydrocarbons (Antonialli-Junior et al., 2007, 2008; Neves et al., 2012, 2013;
Bernardi et al., 2014; Soares et al., 2014; Torres et al., 2014). Due to the versatility of photoacoustic detection, which enables analysis of the optical absorption of materials that are opaque in the infrared region, it can be applied to different systems and various sizes of the sample. The mid-infrared absorption band is sensitive to the vibration of molecular chemical groups, enabling the identification and distinction of molecular radicals and the types of chemical bonds present in a sample.

The present study aimed to evaluate inter- and intraspecific variability in the venom chemical composition of the P. paulista social wasp and the E. brunneum ant using FTIR-PAS.

\section{Materials and methods}

Hymenoptera sample collection

Five colonies of P. paulista wasps (Fig 1A) were collected in Dourados city, Brazil. Three of these colonies were located at the Universidade Estadual de Mato Grosso do Sul (at $22^{\circ} 11^{\prime} 50.1^{\prime \prime} \mathrm{S}, 54^{\circ} 55^{\prime} 48.5^{\prime}$ ” $\mathrm{W}$ ), denoted as "area A", and two colonies were located in the urban area of Dourados (at $22^{\circ} 14^{\prime} 38.8^{\prime \prime} \mathrm{S}, 54^{\circ} 49^{\prime} 36.6^{\prime \prime} \mathrm{W}$ and $22^{\circ} 15^{\prime} 23.5^{\prime \prime} \mathrm{S}$, $54^{\circ} 47^{\prime} 59.1$ ”W), denoted as "area B". The colonies were collected by wrapping plastic bags around the nests and then detaching the nests from the substrates to which they were fixed. Analyses were performed using between 25 and 40 wasps from each colony. The wasps were killed and preserved by freezing, and the samples were stored in Eppendorf vials for subsequent analysis.

The E. brunneum ants (Fig 1B) were collected in the same areas (A and B) where the wasps were sampled. Active individuals were captured randomly at different sites to obtain an adequate representation of the populations, considering possible genetic variability. For each area, 100 forager ants were collected and the contents of their glands were analyzed. The ants were killed and preserved by freezing, in the same methodology described for the wasps.

\section{Extraction and Fourier Transform Infrared Photoacoustic Spectroscopy (FTIR-PAS)}

The FTIR-PAS analyses were performed using a Thermo Nicolet Nexus 670 spectrophotometer, with photoacoustic detection at $4000-400 \mathrm{~cm}^{-1}$. During the experiment, the spectrometer was purged with dry air to remove water vapor. The photoacoustic cell was purged with helium gas before each reading. For standardization, a piece of black carbon was used to collect reference infrared spectra, with a new background measurement being performed every 100 minutes. Spectra were obtained as the average of 128 scans at a resolution at $16 \mathrm{~cm}-1$. In order to enable comparative analysis, the area of each spectrum was determined, and one of them was used to normalize all the spectra. 

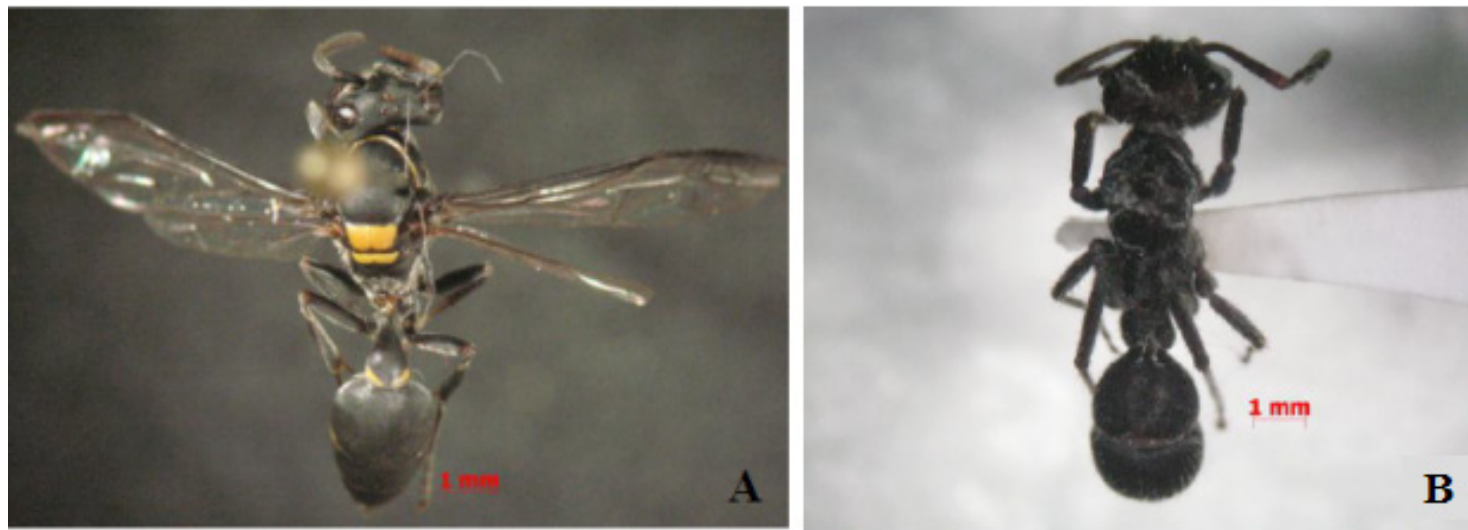

Fig 1. Wasp Polybia paulista (A) and ant Ectatomma brunneum (B). (Mendonça, A.)

The wasps and ants were prepared for the infrared analyses by dissection with tweezers under a stereomicroscope. The glands and their storage reservoirs were extracted by pulling the stinger, and they were immediately placed into a photoacoustic cell crucible and analyzed, to avoid any risk of protein degradation. For each spectrum, five venom reservoirs were inserted into the photoacoustic cell, and 15 spectra were recorded for each colony.

\section{Statistical analysis}

The inter- and intraspecific differences in venom chemical composition of the two species were evaluated by discriminant function analysis (DFA) (Quinn \& Keough, 2002). All absorptions peaks were identified based on literature data (Lin-Vien et al., 1991; Smith, 1999). The main absorption intensities in the infrared spectrum were selected, with the wavenumbers of the absorption peaks as variables and the peak intensities as experimental values. All peaks were integrated and normalized by the sum of the area. The statistical procedure identified the linear combination of variables that provided the best explanation of the differences among the analyzed groups.

The Wilks' lambda statistic parameter was used as a measure of the differences among the groups: values close to zero indicate there is no overlap among the groups, and values close to 1 indicate considerable overlap (Manly, 2008). The squared Mahalanobis distance was used to detect the differences between the species and the collection areas.

\section{Results}

The average photoacoustic infrared spectra obtained for the venoms of $P$. paulista wasps and of E. brunneum ants sampled in different areas are shown in Fig 2. By the spectra, it is possible to identify three regions (highlighted in the figure) that can be used as biomarkers of wasps and ants venoms. The highlighted regions represent the most important differences observed for intra- and interspecific interpretation, which were more precisely confirmed by data from Fig 3 .
The first range of the Fig 2, indicated as (1) around $970-1190 \mathrm{~cm}^{-1}$, corresponds to the absorption of the functional group $\mathrm{C}-\mathrm{H}$ with vibrational mode bending in the plane. It is possible to observe that in this region, the wasp venom has absorption intensity higher than the ant venom. This effect is an indication that the venom chemical composition of $P$. paulista wasp has in its composition aromatic rings in higher concentration than the venom of E. brunneum ant.

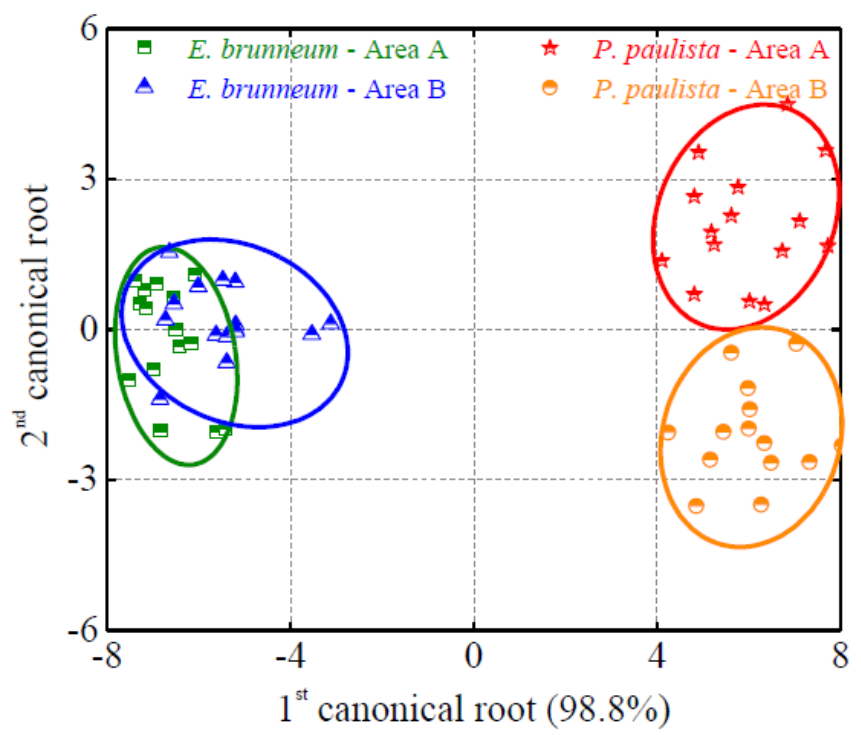

Fig 2. Average infrared absorption spectra of venom glands and reservoirs from Polybia paulista wasps and Ectatomma brunneum ants. The highlighted regions represent the most important differences observed for intra- and interspecific interpretation, which were more precisely confirmed by data from figure 3 .

Following, observing (2) in $1360-1490 \mathrm{~cm}^{-1}$ range, which corresponds to the absorption of the $\delta \mathrm{C}-\mathrm{N}$ functional group from amide I and $\delta \mathrm{CNH}$ from amide II (approximately at 1396 and $1457 \mathrm{~cm}^{-1}$, respectively with vibrational modes defined as stretching and stretch-bend in cis configuration), it is possible to note that the ratio among the intensities of $\delta \mathrm{C}-\mathrm{N}$ and $\delta \mathrm{CNH}(\delta \mathrm{C}-\mathrm{N} / \delta \mathrm{CNH}$ ratio) in the wasps venom spectra is different, if they are compared with the same ratio observed in the ant spectra. Although the amide I and II concentrations 
are different among the studied species, it is impossible to note any difference among the studied area comparing within the species.

Finally, the indication (3) in $2800-3000 \mathrm{~cm}^{-1}$ range shows that $\mathrm{CH}$ composition is strongly different among ants and wasps. By the E. brunneum ant venom spectra is noted that the absorption peak at $2877 \mathrm{~cm}^{-1}$, due to $v_{\mathrm{s}} \mathrm{CH}_{3}$ (symmetric stretching), is less intense if compared to the absorption peaks at 2931 and $2962 \mathrm{~cm}^{-1}$, which correspond to asymmetric stretching of $v_{\text {as }} \mathrm{CH}_{2}$ and $v_{\text {as }} \mathrm{CH}_{3}$, respectively. In opposite, the venom of $P$. paulista wasp exhibits the peak at $2931 \mathrm{~cm}^{-1}$ with higher absorption intensity than the E. brunneum ant venom. It is interesting to note that there is difference in the relationship between the intensities $\mathrm{I}_{1}$ and $\mathrm{I}_{2}$ of the peaks 2931 and $2962 \mathrm{~cm}^{-1}$, respectively: for $P$. paulista species, the $\mathrm{I}_{1} /$ $\mathrm{I}_{2}$ relationship is $>1$ and for area A is higher than area B. In opposite way, for E. brunneum the relation $\mathrm{I}_{1} / \mathrm{I}_{2}$ is $<1$ (Fig 2 ). This was observed for both $A$ and $B$ areas, and suggests that these vibration modes can be used as a reference for distinguishing venom for wasp and ants.

To interpret the infrared data statistically, the mentioned absorption intensities together with other peaks of amide, like $1542 \mathrm{~cm}^{-1}$ due to stretch-bend (trans) of $\delta \mathrm{CNH}$, $1650 \mathrm{~cm}^{-1}$ corresponding to stretching of $\mathrm{C}=\mathrm{N}$, and 3293 $\mathrm{cm}^{-1}$ due to stretching of $v_{\mathrm{s}} \mathrm{N}-\mathrm{H}$, were used as experimental data, using the wavenumbers as the variables, it was possible to construct a matrix to discriminate the four investigated groups. Fig 3 shows the obtained scatter plot by the statistical analysis. It reveals that the differences among venom chemical composition of ants and wasps are significant (Wilks' lambda $=0.005 ; \mathrm{F}=14.347 ; \mathrm{p}<0.001$ ).

The first canonical root explains $98.8 \%$ of the differences, being the most important root to discriminate among the venom of wasps and ants. Among the investigated infrared absorption peaks, those at 1041, 1079 and $1157 \mathrm{~cm}^{-1}$

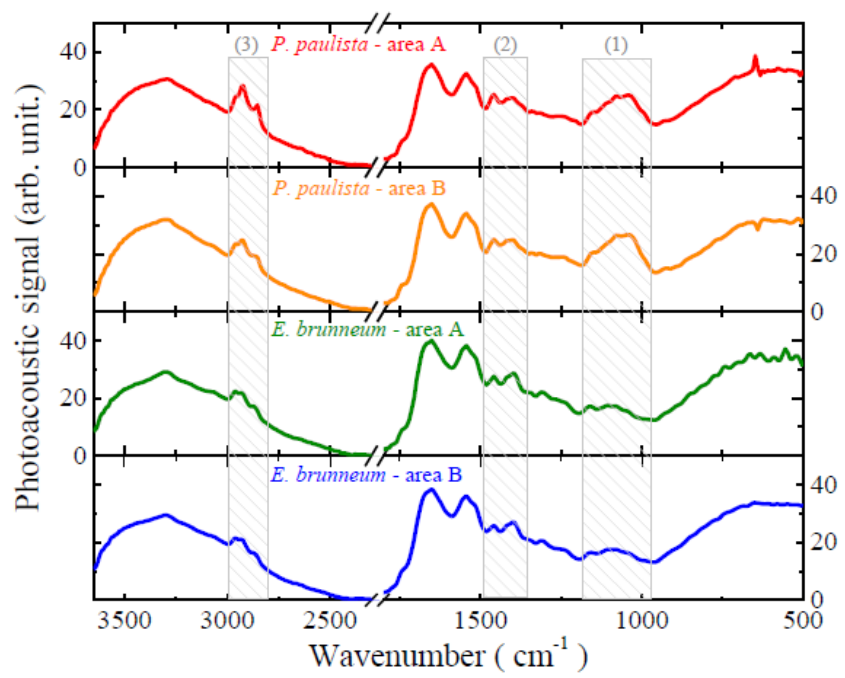

Fig 3. Scatter plot showing the differences in venom chemical composition among Polybia paulista wasps and Ectatomma brunneum ants collected in two different areas (A and B) of Dourados-MS. were significant to separate the groups. These peaks are located in the highlighted region (1) in Fig 2. The second canonical root differentiates the area A from B for P. paulista wasps, while the venom chemical composition of $E$. brunneum ants is similar among the areas A and B. The squared Mahalanobis distances obtained with the infrared experimental data are listed in Table 1, confirming that the P. paulista wasps and $E$. brunneum ants venom chemical composition are significantly different $(\mathrm{p}<0.001)$.

Table 1. Squared Mahalanobis distances between groups of Polybia paulista wasps and Ectatomma brunneum ants, comparing the venom chemical composition among samples from two different areas of Dourados-MS.

\begin{tabular}{lllll}
\hline & $\begin{array}{l}\text { P. paulista } \\
\text { area A }\end{array}$ & $\begin{array}{l}\text { P. paulista } \\
\text { area B }\end{array}$ & $\begin{array}{l}\text { E. brunneum } \\
\text { area A }\end{array}$ & $\begin{array}{l}\text { E. brunneum } \\
\text { area B }\end{array}$ \\
\hline $\begin{array}{l}P \text { p paulista } \\
\text { area A }\end{array}$ & 0.000 & 18 & 164 & 135 \\
$\begin{array}{l}\boldsymbol{P} \text { paulista } \\
\text { area B }\end{array}$ & 18 & 0.000 & 170 & 142 \\
$\begin{array}{l}\text { E. brunneum } \\
\text { area A }\end{array}$ & 164 & 170 & 0.000 & 5 \\
$\begin{array}{l}\text { E. brunneum } \\
\text { area B }\end{array}$ & 135 & 142 & 5 & 0.000 \\
\hline
\end{tabular}

\section{Discussion}

The results indicate that the chemical composition of venom of wasps and ants are significantly different, independent if they were sampled in areas A or B. This can be seen as well the absorption spectra in the medium infrared (Fig. 2) as by the statistical interpretation of the data (Fig. 3). Comparing the spectra of $P$. paulista wasps collected in areas $\mathrm{A}$ and $\mathrm{B}$ it is possible to notice a high degree of similarity. This can be confirmed by Fig. 3, where the ellipses of wasps and ants are practically aligned with respect to the first canonical root, which accounts for $98.8 \%$ of the data.

This observation can be explained by genetic factors since the insects belong to different families. This result has been observed previously in works concerning the influence of the environmental component on venom chemical composition (Tsai et al., 2004; Badhe et al., 2006; AbdelRahman et al., 2011; Cologna et al., 2013). Studies with social Hymenoptera have also shown that genetic factors and age can be responsible for the venom chemical composition and some compounds are characteristic of particular species (Ferreira-Junior et al., 2010; Cologna et al., 2013).

Similar variation in venom chemical composition among species has also been reported for snakes (Daltry et al., 1996). In this case, it was observed that snakes born in captivity had venom chemical composition similar to those of wild snakes collected in the same region of origin of those kept in captivity. The authors suggest that the association between the venom chemical composition and the prey is an inherited characteristic and is not induced by the environment. 
However, venom is a complex mixture of substances and the variation in its chemical composition cannot be attributed to any single factor. Studies have found that in addition to genetic factors, environmental variables, such as geographic location and climate, can also affect the distribution of food and therefore influence the diets of the organisms (Tsai et al., 2004; Badhe et al., 2006; Abdel-Rahman et al., 2009, 2011; Cologna et al., 2013). Hence, environmental factors also exert an influence on venom chemical composition.

The studies of Mendonça et al. (2017) analyzing the venom of $P$. paulista and Bernardi et al. (2017) with $E$. brunneum, both by FTIR-PAS, highlight the environmental effect on the chemical profiles of venom. In addition, Mendonça et al. (2017) discuss that both environmental and genetic factors can affect the composition of $P$. paulista venom, since venom of wasps from nesting colonies in closer areas are more similar than those of more distant ones, because the former have the closest kinship level and share the same type of environments. Variations in venom chemical composition according to the location was also observed in Maurus palmatus scorpions (Abdel-Rahman et al., 2009).

Studies analyzing only the protein portion of the $P$. paulista venom also show variation in the chemical composition between different colonies (Dias et al., 2014), as well as studies with ants that found variation in the venom composition of colonies of the same population (Aili et al., 2017), in which the authors suggested genetic polymorphism or small environmental variations between areas.

The results presented here corroborate the findings of Badhe et al. (2006), who evaluated the role of genetic factors in different populations of red scorpions (Mesobuthus tamulus) and suggested the existence of genetic variation among the populations. Nonetheless, it concludes that environmental conditions also significantly affected the lethality of the venom.

It can be seen from Fig 3 that there is no overlap among the ellipses for the venom chemical composition of wasp from different colonies (areas A and B), opposing to the observed for the ants venom chemical composition. This effect can be explained by the difference in food resources utilized by each species. Wasps often prey on the larvae of Lepidoptera (Giannotti et al., 1995; Prezoto et al., 2006; Bichara-Filho et al., 2009; Fernandes et al., 2010), which should result in differences between the two sampled areas regarding venom chemical composition. On the other hand, E. brunneum ant as well as other ants of this genus, prey on a greater diversity of organisms (Overal, 1986; Giannotti \& Machado, 1992; Marques et al., 1995), leading to a potential dilution of the differences between the two sampled areas. An additional and essential point to be considered is that wasps fly further from the nest to forage.

Therefore, the diversity of plants visited by wasps is likely to be greater, which might influence the venom chemical composition. The influence of diet on the composition of $E$. brunneum venom was also reported by Bernarid et al. (2017). In a study with Dinoponera quadriceps ants sampled from four different regions, Cologna et al. (2013) noted that the venoms of individuals collected in the closest areas showed greater similarity when compared to the venom of specimens collected in far regions. Among the 335 compounds detected in the venom, only 48 were shared by all four colonies, indicating that the environment highly influenced the venom chemical composition.

In fact, studies have shown that some animals can synthesize the venom from precursors or sequester the chemical elements of the environment through diet to compose their venom (Savitzky et al., 2012). Therefore, environmental as well as genetic factors significantly influence the venom composition of different species of animals.

Thus, it is clear that the two species synthesize significantly different elements to compose their venoms. These differences have a genetic basis, however, as reported in the literature, exogenous factors may also be determinant to compose the differences between the venom of different populations of a species, especially in this case that of social wasps.

\section{Conclusions}

We can conclude that there is a significant difference between the venom chemical composition of ants and wasps and the genetic component seems to be predominant in determining the compounds of venom. This proves that the venom chemical composition varies among families in the Hymenoptera. On the other hand, exogenous factors such as the diet in different environments can be responsible for intraspecific differences, particularly in social wasps. Finally, statistical analysis applied to the infrared absorption data obtained by FTIR-PAS proved to be a reliable and efficient methodology for evaluating differences in the venom chemical composition of social Hymenoptera. Therefore, the methodology can be used as an auxiliary taxonomic tool.

\section{Acknowledgements}

The authors thank Dr. Orlando T. Silveira (Museu Paraense Emílio Goeldi, MPEG) for the identification of the species, Fundação de Apoio ao Desenvolvimento do Ensino, Ciência e Tecnologia do Estado de Mato Grosso do Sul (Fundect), Coordenação de Aperfeiçoamento de Pessoal de Nível Superior (CAPES), and Universidade Estadual de Mato Grosso do Sul (UEMS). WFAJ, LHCA, and SML acknowledge research grants from Conselho Nacional de Desenvolvimento Científico e Tecnológico (CNPq).

\section{Authors' Contribution}

The original idea for this research was conceived by A Mendonça and WF Antonialli Junior. A Mendonça, 
RC Bernardi, ELB Firmino, LHC Andrade and SM Lima performed the experiments and analyzed the data. A Mendonça drafted the manuscript. All the authors reviewed and approved the final manuscript.

\section{References}

Abdel-Rahman, M.A., Omran, M.A.A., Abdel-Nabi, I.M., Ueda, H. \& Mcvean, A. (2009). Intraspecific variation in the Egyptian scorpion Scorpio maurus palmatus venom collected from different biotopes. Toxicon, 53:349-359. doi: 10.1016/j. toxicon.2008.12.007

Abdel-Rahman, M.A., Abdel-Nabi, I.M., El-Naggar, M.S., Abbas, O.A. \& Strong, P.N. (2011). Intraspecific variation in the venom of the vermivorous cone snail Conus vexillum. Comparative Biochemistry and Physiology Part C: Toxicology \& Pharmacology, 154:318-325. doi: 10.1016/j. cbpc.2011.06.019

Aili, S. R., Touchard, A., Koh, J. M. S., Dejean, A., Orivel, J., Padula, M. P., Escoubas, P. \& Nicholson, G. M. (2016). Comparisons of Protein and Peptide Complexity in Poneroid and Formicoid Ant Venoms. Journal of Proteome Research, 15(9), 3039-3054. doi:10.1021/acs. jproteome.6b00182

Aili, S.R., Touchard, A., Petitclerc, F., Dejean, A., Orivel, J., Padula, M.P., Escoubas, P., Nicholson, G.M.(2017). Combined peptidomic and proteomic analysis of electrically stimulated and manually dissected venom from the South American bullet ant Paraponera clavata. Journal of Proteome Research, 16: 1339-1351. doi:10.1021/acs.jproteome.6b00948

Antonialli-Junior, W.F., Lima, S.M., Andrade, L.H.C. \& Súarez, Y.R. (2007). Comparative study of the cuticular hydrocarbon in queens, workers and males of Ectatomma vizottoi (Hymenoptera, Formicidae) by Fourier transform infrared photoacoustic spectroscopy. Genetics and Molecular Research, 6:492-499.

Antonialli-Junior, W.F., Suarez, Y.R., Izida, T., Andrade, L.H.C. \& Lima, S.M. (2008). Intra- and interspecific variation of cuticular hydrocarbon composition in two Ectatomma species (Hymenoptera: Formicidae) based on Fourier transform infrared photoacoustic spectroscopy. Genetics and Molecular Research, 7:559-566. doi: 10.4238/vol7- 2 gmr454.

Badhe, R.V., Thomas, A.B., Harer, S.L., Deshpande, A.D., Salvi, N. \& Waghmare, A. (2006) Intraspecific variation in protein of red scorpion (Mesobuthus tamulus, Coconsis, Pocock) venoms from Western and Southern India. Journal of Venomous Animals and Toxins including Tropical Diseases, 12:612-619. doi:10.1590/s1678-91992006000400008

Baracchi, D. \& Tragust, S. (2017). Venom as a Component of External Immune Defense in Hymenoptera. Evolution of Venomous Animals and Their Toxins, 213-233.
Bernardi, R.C., Firmino, E.L.B., Pereira, M.C., Andrade, L.H.C., Cardoso, C.A.L., Súarez, Y.R., Antonialli-Junior, W.F. \& Lima, S.M. (2014). Fourier transform infrared photoacoustic spectroscopy as a potential tool in assessing the role of diet in cuticular chemical composition of Ectatomma brunneum. Genetics and Molecular Research, 13:1003510048. doi: doi.org/10.4238/2014.November.28.8.

Bernardi, R.C., Firmino, E.L.B., Mendonça, A., SguariziAntonio, D., Pereira, M.C., Andrade, L.H.C., AntonialliJunior, W.F. \& Lima, S.M. (2017). Intraspecific variation and influence of diet on the venom chemical profile of the Ectatomma brunneum Smith (Formicidae) ant evaluated by photoacoustic spectroscopy. Journal of Photochemistry and Photobiology B: Biology, 175: 200-206.doi:10.1016/j. jphotobiol.2017.09.004

Bichara-Filho, C.C., Santos, G.M.M., Resende, J.J., Cruz, J.D., Gobbi, N. \& Machado, V.L.L. (2009). Foraging behavior of the swarm-founding wasp, Polybia (Trichothorax) sericea (Hymneoptera, Vespidae): prey capture and load capacity. Sociobiology, 53:61-69.

Carpenter, J.M. \& Marques, O.M. (2001). Contribuição ao estudo dos vespídeos do Brasil (Insecta, Hymenoptera, Vespoidea, Vespidae). Universidade Federal da Bahia, Departamento de Fitotecnia. Série publicações digitais 02, 147p.

Casewell, N.R., Wüster, W., Vonk, F.J., Harrison, R.A. \& Fry, B.G. (2013). Complex cocktails: the evolutionary novelty of venoms. Cell. Press, 28: 219-29. doi.org/10.1016/j. tree.2012.10.020

Cologna, C.T., Cardoso, J.S., Jourdan, E., Degueldre, M., Upert, G., Gilles, N., Uetanabaro, A.P.T., Neto, E.M.C., Trovatti, P., Pauw, E. \& Quinton, L. (2013). Peptidomic comparison and characterization of the major components of the venom of the giant ant Dinoponera quadriceps collected in four different areas of Brazil. Journal of Proteomics, 94:413-422. doi:10.1016/j.jprot.2013.10.017

Daltry, J.C., Wüster, W. \& Thorpe, R.S. (1996) Diet and snake venom evolution. Nature, 379:537-540. doi:10.1038/379537a0

Dias, N.B., Souza, B.M., Gomes, P.C. \& Palma, M.S. (2014). Peptide diversity in the venom of the social wasp Polybia paulista (Hymenoptera): A comparison of the intra- and inter-colony compositions. Peptides, 51: 122-130. doi:10.1016/j.peptides.2013.10.029

Dias, N.B., Souza, B.M., Gomes, P.C., Brigatte, P. \& Palma, M.S. (2015). Peptidome profiling of venom from the social wasp Polybia paulista. Toxicon, 107: 290-303.doi:10.1016/j. toxicon.2015.08.013

Edstrom, A. (1992). Venomous and Poisonous Animals. Malabar, Krieger Publishing Company, 210p.

Fernandes, F.L., Sena, F.M.E., Picanco, M.C., Geraldo, G.C., Demuner, A.J. \& Silva, R.S. (2010). Coffee volatiles and 
predatory wasps (Hymenoptera: Vespidae) of the coffee leaf miner Leucoptera coffeella. Sociobiology, 56:455- 464.

Ferreira Junior, R.S., Sciani, J.M., Marques-Porto, R., Junior, A.L., Orsi, R.O., Barraviera, B. \& Pimenta, D.C. (2010). Africanized honey bee (Apis mellifera) venom profiling: Seasonal variation of melittin and phospholipase A(2) levels. Toxicon, 56:355-362. doi: 10.1016/j.toxicon.2010.03.023

Giannotti, E. \& Machado, V.L.L. (1992). Notes on the foraging of two species of Ponerinae ants: Food and resources and daily hunting activities (Hymenoptera: Formicidae). Bioikos, 6:7-17.

Giannotti, E., Prezoto, F. \& Machado, V.L.L. (1995). Foraging activity of Polistes lanio lanio (Fabr.) (Hymenoptera: Vespidae). Anais da Sociedade Entomológica do Brasil, 24:455-463.

Gomes, L., Desuó, I.C., Gomes, G. \& Giannotti, E. (2009). Behavior of Ectatomma brunneum (Formicidae: Ectatomminae) preying on dipterans in field conditions. Sociobiology, 53:913-926.

Gomes, P.C., Souza, B.M., Dias, N.B., Brigatte, P., Mourelle, D., Arcuri, H. A., Cabrera, M.P.S., Stabeli, R.G., Neto, J.R. \& Palma, M.S. (2014). Structure-function relationships of the peptide Paulistine: A novel toxin from the venom of the social wasp Polybia paulista. Biochimica et Biophysica Acta (BBA) - General Subjects, 1840: 170-183.doi:10.1016/j. bbagen.2013.08.024

Hoshina, M.M., Santos, L.D., Palma, M.S. \& MarinMorales, M.A. (2013). Cytotoxic, genotoxic/antigenotoxic and mutagenic/antimutagenic effects of the venom of the wasp Polybia paulista. Toxicon, 72: 64-70.doi:10.1016/j. toxicon.2013.06.007

Jacomini, D. L.J., Pereira, F.D.C., Pinto, J.R.A.S., Santos, L.D., Silva Neto, A.J., Giratto, D.T., Palma, M.S., Zollner, R.L. \& Brochetto Braga, M.R. (2013). Hyaluronidase from the venom of the social wasp Polybia paulista (Hymenoptera, Vespidae): Cloning, structural modeling, purification, and immunological analysis. Toxicon, 64:70-80. doi: 10.1016/j. toxicon.2012.12.019

Kempf, W.W. (1992). Catálogo abreviado das formigas da região neotropical (Hymenoptera: Formicidae). Studia Entomologica, 15:1-344.

Leite, N.B., Aufderhorst-Roberts, A., Palma, M.S., Connell, S.D., Neto, J.R. \& Beales, P.A. (2015). PE and PS lipids synergistically enhance membrano poration by a peptide with anticancer properties. Biophysical Journal, 109: 936-947. doi: 10.1016/j.bpj.2015.07.033

Lima, P.R.M. \& Brochetto-Braga, M.R. (2003). Hymenoptera venom review focusing on Apis melifera. Journal of Venomous Animals and Toxins including Tropical Diseases, 9:149-162. doi: 10.1590/S1678-91992003000200002
Lin-Vien, D., Colthup, N.B., Fateley, W.G. \& Grasselli, J.G. (1991). Infrared and Raman Characteristic Frequencies of Organic Molecules. New York, Academic Press, 156p.

Macalintal, E.A. \& Starr, C.K. (1996). Comparative morphology of the stinger in the social wasp genus Ropalidia (Hymenoptera: Vespidae). Memoirs the Entomological Society of Washington, 17:108-150.

Manly, B.J. F. (2008). Métodos Estatísticos Multivariados: Uma Introdução. $3^{\mathrm{a}}$ edição, Porto Alegre, Bookman, 230p.

Manzoli-Palma, M.S.C \& Gobbi, N. (1997). Muscles-bearing of sting apparatus in social wasp and their relationship with the autotomy (Hymenoptera: Vespidae: Polistinae). Journal of Advanced Zoology, 18:1-6.

Marques, O.M., Viana, C.H.P., Kamoshida, M., Carvalho, C.A.L. \& Santos, G.M.M. (1995). Hábitos de nidificação e alimentares de Ectatomma quadridens (Fabricius, 1793) (Hymenoptera, Formicidae) em Cruz das Almas-Bahia. Insecta 4:1-9.

Mateus, S. (2011). Observations on forced colony emigration in Parachartergus fraternus (Hymenoptera: Vespidae: Epiponini): New nest site marked with sprayed venom. Psyche: A Journal of Entomology, 2011:1-8. doi: $10.1155 / 2011 / 157149$

Mendonça, A., Paula, M.C., Fernandes, W.D., Andrade, L.H.C., Lima, S.M., Antonialli-Junior, W.F. (2017). Variation in venoms of Polybia paulista Von Ihering and Polybia ccidentalis Olivier (Hymenoptera: Vespidae), assessed by the FTIR-PAS technique. Neotropical Entomology, 45:1-10. doi: 10.1007/s13744-016-0426-6.

Neves, E.F., Andrade, L.H.C., Suarez, Y.R., Lima, S.M \& Antonialli-Junior, W.F. (2012). Age-related changes in the surface pheromones of the wasp Mischocyttarus consimilis (Hymenoptera: Vespidae). Genetics and Molecular Research, 11:1891-1898. doi: 10.4238/2012.July.19.8.

Neves, E.F., Montagna, T.S., Andrade, L.H.C., Súarez, Y.R., Lima, S.M. \& Antonialli-Junior, W.F.(2013). Social parasitism and dynamics of cuticular hydrocarbons in paper wasp of the Mischocyttarus. Jounal of the Kansas Entomological Society, 86:69-77. doi: 10.2317/JKES1207610.1.

Orivel, J., Redeker, V., Le Caer, J.P., Krier, F., Revol-Junelles, A.M., Longeon, A., Chaffotte, A., Dejean, A. \& Rossier, J.P. (2001). Ponericins, new antibacterial and insecticidal peptides from the venom of the ant Pachycondyla goeldii. Journal of Biological Chemistry, 276:17823-17829. doi: 10.1074/jbc. M100216200

Overal, W.L. (1986). Recrutamento e divisão de trabalho em colônias naturais da formiga Ectatomma quadridens (Fabr.) (Hymenoptera: Formicidae: Ponerinae). Boletim do Museu Paraense Emílio Goeldi. Nova série. Zoologia, 2:113-135. 
Palma, M.S. (2006). Insect venom peptides. In: Kastin, A.J. (Org.). The Handbook of Biologically Active Peptides. Oxford, Academic Press, p. 409-416.

Perez-Riverol, A., Fernandes, L.G.R., Lasa, A. M., Pinto, J. R. A. S., Abram, D.M., Moraes, G.H.I., Jabs, F., Miehe, M., Seismman, H., Palma, M. S., Zollner, R.L., Spillner, E. \& Brochetto-Braga, M.R. (2018). Phospholipase A1-based cross-reactivity among venoms of clinically relevant Hymenoptera from Neotropical and temperate regions. Molecular Immunology, 93: 87-93.doi:10.1016/j. molimm.2017.11.007

Pinto, J.R.A. S., Santos, L.D., Arcuri, H.A., Dias, N.B. \& Palma, M.S. (2012). Proteomic characterization of the hyaluronidase (E.C. 3.2.1.35) from the venom of the social wasp Polybia paulista. Protein \& Peptide Letters, 19: 625635. doi: $10.2174 / 092986612800494039$

Pluzhnikov, K. A., Kozlov, S. A., Vassilevski, A. A., Vorontsova, O. V., Feofanov, A. V. \& Grishin, E. V. (2014). Linear antimicrobial peptides from Ectatomma quadridens ant venom. Biochimie, 107, 211-215. doi: 10.1016/j.biochi.2014.09.012

Prezoto, F., Santos-Prezoto, H.H., Machado, V.L.L. \& Zanuncio, J.C. (2006). Prey captured and used in Polistes versicolor (Olivier) (Hymenoptera: Vespidae) nourishment. Neotropical Entomology, 35:707-709. doi:10.1590/S1519566X2006000500021.

Quinn, G.P. \& Keough, M.J. (2002). Experimental design and data analysis for biologists. Cambridge, Cambridge University Press, 530p.

Richards, O.W. (1978). The Social Wasps of America Excluding the Vespinae. London, British Museum (Natural History), 580p.

Santos, L.D., Menegasso, A.R.S., Pinto, J.R.A.S., Santos, K.S., Castro, F.M., Kalil, J.E. \& Palma, M.S. (2011). Proteomic characterization of the multiple forms of the PLAs from the venom of the social wasp Polybia paulista, Proteomics, 11: 1403-1412. doi: 10.1002/pmic.201000414

Savitzky AH, Mori A, Hutchinson DA, Saporito RA, Burghardt GM, Lillywhite HB, Meinwald J(2012) Sequestered defensive toxins in tetrapod vertebrates: principles, patterns, and prospects for future studies. Chemoecology 22:141-158. doi: 10.1007/s00049-012-0112z

Schmidt, J.O. (1982). Biochemistry of insect venoms. Annual Review Entomology, 27: 339-368. doi: 10.1146/annurev. en.27.010182.002011

Smith, B.C. (1999). Infrared Spectral Interpretation: A Systematic Approach. Boca Raton, Florida: CRC Press.

Soares, E.R.P., Torres, V.O. \& Antonialli-Junior, W.F. (2014). Reproductive status of females in the eusocial wasp Polistes ferreri Saussure (Hymenoptera: Vespidae). Neotropical Entomology, 43:500-508. doi: 10.1007/s13744-014-0242-9.

Souza, B.M., Silva, A.V.R., Resende, V.M.F., Arcuri, H.A., Cabrera, M.P.S., Ruggiero Neto, J. \& Palma, M.S. (2009). Characterization of two novel polyfunctional mastoparan peptides from the venom of the social wasp Polybia paulista. Peptides, 30(8), 1387-1395. doi: 10.1016/j. peptides.2009.05.008

Torres, V.O., Sguarizi-Antonio, D., Lima, S.M., Andrade, L.H.C. \& Antonialli-Junior, W.F. (2014). Reproductive status of the social wasp Polistes versicolor (Hymenoptera, Vespidae). Sociobiology, 61(2):218-224. doi: 10.1007/ s002650050498

Touchard, A., Koh, J. M. S., Aili, S. R., Dejean, A., Nicholson, G. M., Orivel, J. \& Escoubas, P. (2015). The complexity and structural diversity of ant venom peptidomes is revealed by mass spectrometry profiling. Rapid Communications in Mass Spectrometry, 29: 385-396. doi: 10.1002/rcm.7116.

Tsai, H.I., Wang, Y.M., Chen, Y.H., Tsai, T.S. \& Tu, M.C. (2004). Venom phospholipases A2 of bamboo viper (Trimeresurus stejnegeri): molecular characterization, geographic variations and evidence of multiple ancestries. Biochemical Journal, 377:215-223. doi: 10.1042/BJ20030818

Vinhote, J.F.C., Lima, D.B., Menezes, R.R.P.P.B., Mello, C.P., Souza, B.M., Havt, A., Palma, M.S., Santos, R.P., Albuquerque, E.L., Freire, V.N. \& Martins, A.M.C. (2017). Trypanocidal activity of mastoparan from Polybia paulista wasp venom by interaction with TcGAPDH, Toxicon, 137: 168-172. doi: 10.1016/j.toxicon.2017.08.002

Wilson, E.O. (1971). The Insect Societies. Cambridge, Belknap Press, 548p. 